\title{
MANAGING TRAFFIC SAFETY EDUCATION ACTIVITIES IN PRIMARY SCHOOLS: STATUS, NECESSITY, AND INFLUENCING FACTORS
}

\author{
GERENCIAMENTO DAS ATIVIDADES DE EDUCAÇÃO PARA SEGURANÇA NO \\ TRÂNSITO NAS ESCOLAS PRIMÁRIAS: ESTADO, NECESSIDADE E FATORES DE \\ INFLUÊECIA
}

\begin{abstract}
GESTIÓN DE LAS ACTIVIDADES DE EDUCACIÓN EN SEGURIDAD TRÁFICA EN ESCUELAS PRIMARIAS: ESTADO, NECESIDAD Y FACTORES QUE INFLUYEN
\end{abstract}

Van VU HONG ${ }^{1}$

\begin{abstract}
Over the years, traffic safety has been taught and has become a common subject in Vietnamese primary schools. Educational activities take place in both formal and extra-curricular educational activities. However, traffic safety education and management of traffic safety education in schools have not received adequate attention. Implementation activities are still formal, have not shown continuity, long-term and drastic; the coordination with other educational forces is not synchronized, etc. Therefore, the effect achieved in traffic safety education in schools is not high. Aware of the importance of this activity, based on the actual survey in 04 selected primary schools, with 84 people being administrators and teachers; The study focuses on analyzing the current situation, necessity, and problems posed in traffic safety education management activities in primary schools.
\end{abstract}

KEYWORDS: Managing. Traffic safety. Education activities. Primary schools. Ho Chi Minh City. Vietnam.

RESUMO: Ao longo dos anos, a segurança no trânsito foi ensinada e se tornou um assunto comum nas escolas primárias vietnamitas. As atividades educacionais ocorrem em atividades educacionais formais e extracurriculares. No entanto, a educação para a segurança no trânsito e a gestão da educação para a segurança no trânsito nas escolas não têm recebido atenção adequada. As atividades de implementação ainda são formais, não mostraram continuidade, de longo prazo e drásticas; a coordenação com outras forças educacionais não é sincronizada, etc. Portanto, o efeito alcançado na educação de segurança no trânsito nas escolas não é alto. Consciente da importância desta atividade, com base no levantamento realizado em 04 escolas primárias selecionadas, com 84 pessoas sendo administradores e professores; $O$ estudo se concentra em analisar a situação atual, a necessidade e os problemas colocados nas atividades de gestão de educação para a segurança no trânsito nas escolas primárias.

PALAVRAS-CHAVE: Gestão. Segurança no trânsito. Atividades de educação. Escolas primárias. Cidade de Ho Chi Minh. Vietnã.

${ }^{1}$ University of Transport and Communications (UTC), Hanoi - Vietnam. PhD, Faculty of Political Theory. ORCID: https://orcid.org/0000-0003-3867-1865. E-mail: vhvan_ph@utc.edu.vn 
RESUMEN: A lo largo de los años, la seguridad vial se ha enseñado y se ha convertido en una materia común en las escuelas primarias vietnamitas. Las actividades educativas tienen lugar en actividades educativas tanto formales como extracurriculares. Sin embargo, la educación sobre seguridad vial y la gestión de la educación sobre seguridad vial en las escuelas no han recibido la atención adecuada. Las actividades de implementación son todavía formales, no han mostrado continuidad, son de largo plazo y drásticas; la coordinación con otras fuerzas educativas no está sincronizada, etc. Por lo tanto, el efecto logrado en la educación vial en las escuelas no es alto. Conscientes de la importancia de esta actividad, a partir de la encuesta real en 04 escuelas primarias seleccionadas, con 84 personas como administradores y docentes; El estudio se centra en analizar la situación actual, la necesidad y los problemas planteados en las actividades de gestión de la educación en seguridad vial en las escuelas primarias.

PALABRAS CLAVE: Gestión. Seguridad vial. Actividades de educación. Escuelas primarias. Ciudad Ho Chi Minh. Vietnam.

\section{Introduction}

Worldwide, traffic accidents are one of the leading causes of human death. According to the report of the World Health Organization (WHO) and the World Bank (WB), every year, more than 1.2 million people die in road traffic accidents worldwide and about 50 million others are injured. in those accidents. According to WHO, "in developing countries, traffic safety is getting worse due to rapid and unplanned urbanization. Weak infrastructure, flawed legal system cause traffic accidents to increase exponentially. These two agencies warn, if governments do not take measures to prevent this situation, in the following years, traffic accidents will become the third leading cause of death in humans.

Traffic accidents have caused great economic losses such as the cost of dealing with consequences for the deceased, medical expenses for the injured, damage to means of transport and infrastructure; the costs of remedial and investigation of traffic accidents. Along with the damage caused, traffic accidents also waste the working time of the accident victims themselves and also those who take care of the victims (TRUNG; VAN, 2020). On the other hand, traffic accidents cause both immediate and long-term psychological impacts on people, leaving heavy psychological sequelae for accident victims and their loved ones. If there are too many traffic accidents in a locality, a country, it will cause insecurity for people living (HANG; VAN, 2020; VAN, 2020).

In Vietnam, according to the annual statistics of the General Statistics Office (2018; 2019; 2020), traffic accidents often occur with a large number of casualties, specifically: In 2018 more than 18,700 cases, causing more than 8,200 deaths, about 14,800 injuries. In 2019, 
there were 17,626 cases, including 9,229 traffic accidents of less serious or more and 8,397 traffic collisions, causing 7,624 deaths; 13,624 people were injured and 8,528 people were slightly injured. Particularly in 2020, according to statistics of the National Traffic Safety Committee, in the past 12 months (from December 15, 2019, to December 14, 2020), there were 14,510 cases nationwide, killing 6,700 people and injuring 10,804 people.

As for children of primary school age, according to statistics from the Ministry of Health, every year, about 1,900 children die from traffic accidents, accounting for $24-26 \%$ of the total number of children dying from accidents. In which, accidents in inner cities accounted for 68\% (MINISTRY OF HEALTH, 2018; 2019; 2020). According to Mr. JEFFERY KOBZA, acting Chief Representative of WHO in Vietnam (2019), "Injuries and deaths from road traffic accidents are an increasingly important health issue. Road traffic accidents are the leading cause of death for children aged 10 to 19 in Viet Nam, claiming about 2,000 lives each year".

Faced with the actual situation of increasing traffic accidents, Directive No. 18CT/TW of the 11th Secretariat of the Secretariat on strengthening the Party's leadership in ensuring traffic safety on roads, railways and roads inland waterways and traffic jams have been issued; conclusion No. 45-KL/TW dated February 1, 2019, of the Secretariat on continuing to promote effective implementation of Directive No. 18-CT/TW of the Secretariat of the XI term. Next, is Resolution No. 12/NQ-CP dated February 19, 2019, on enhancing traffic safety and order and combating traffic congestion in the period of 2019 - 2021, which proposed many practical actions to minimize the risk of traffic congestion. or can reduce the pain and loss of damage to people as well as property, affecting the overall development of the country. However, the current implementation of traffic safety still faces many difficulties and challenges such as the progress of construction and development of traffic infrastructure is still very slow compared to the growth rate of the number of private vehicles; the management of personal transport is not very effective; the control of the increase in personal transport is still arduous because of the increasing demand for use, while the transport infrastructure is not synchronous; In particular, the implementation of traffic regulations and regulations of the people is still not really self-conscious and serious, it is difficult to propagate and educate traffic awareness to each person in the area and locality, etc (DIRECTORATE FOR ROADS, 2020).

From the above situation, it can be seen that one of the most important issues to contribute to the implementation of traffic safety is to educate the awareness of road users from the time they are still in school. For many years now (from 2015 to 2020), the Ministry 
of Education and Training has coordinated with the Ministry of Public Security and the National Traffic Safety Committee to direct traffic safety education to be integrated into regular classes and organize extra-curricular sessions; in order to bring the content of the traffic safety education program into schools, and at the same time promote the propaganda and dissemination of traffic safety law education for all students at all levels, school level in general and primary school level in particular, in order to contribute to raising the sense of respect and strict observance of the Traffic Law (DAO; VAN, 2020; LUONG; VAN, 2021); know how to protect their own lives and property for themselves, their families and society. It is very necessary to educate children and teenagers to understand traffic laws and build good habits of obeying traffic laws. From a young age, at primary school age, children learn some basic knowledge about traffic laws, helping them to be confident when participating in traffic. However, the biggest challenge today is the implementation of traffic safety education in schools. In other words, the organization and management of traffic safety education still have many problems, causing traffic safety education activities to not achieve the desired results.

\section{Purpose and Mission of Research}

Research purpose: On the basis of theoretical research and analysis and assessment of the current situation of traffic safety education management (road) in primary schools in An Thanh ward, from which, some management measures are proposed traffic safety education activities, in order to improve the quality of traffic safety education in primary schools in Ho Chi Minh City.

Research mission:

Systematize the theoretical basis of traffic safety education and manage traffic safety education activities.

Survey and assess the current situation of traffic safety education and road traffic safety education management for primary school students, selecting 4 primary schools in Ho Chi Minh City to conduct the survey.

Identify the basis and propose measures to improve the quality of traffic safety education management in primary schools in Ho Chi Minh City. 


\section{Objects, Objects, Research Scope, and Research Hypothesis}

Research object: Managing traffic safety education activities in primary schools.

Research object: Measures to manage traffic safety education in primary schools in Ho Chi Minh City.

Research scope:

The population of the survey was 84 people in four primary schools in Ho Chi Minh City, of which: 8 administrators (Principal and Vice-Principal); 20 teachers; 56 CBs in charge of Teams, professional team leaders;

Content limitation: Road safety education;

Research area: 4 primary schools in Ho Chi Minh City;

Time to study the situation: in 2019 and 2020;

Subject of management measures: Principal and Vice-Principal of Primary School.

Scientific hypothesis: The current management of traffic safety education activities for students in primary schools in Ho Chi Minh City is not really synchronous and ineffective. Analyze the current situation and causes, identify establishments that will come up with effective management measures, contribute to improving the effectiveness of traffic safety education for elementary school students, thereby initially educating students. Students have a sense of self-discipline to perform well, strictly abide by the Road Traffic Law and behave culturally when participating in traffic.

\section{Research Methods}

\section{Group Of Theoretical Research Methods}

Researching scientific documents related to the topic, educational management documents related to primary schools, guiding documents on traffic safety education, Government Decrees, Road Traffic Law, etc.

Learn about traffic safety education materials and traffic safety education solutions of developed countries with traffic patterns similar to ours.

Researching documents including theoretical research related to traffic safety education management issues, specifically: Concepts, roles, components, and implementation steps of traffic safety education activities; research projects related to traffic education. 


\section{Group Of Practical Research Methods}

Statistical methods:

Collect information from statistics, backup of the Department of Transport and traffic safety departments of Ho Chi Minh City;

Observational method: Observing traffic behavior of students and parents at primary schools in Ho Chi Minh City at the locations with the most and the fewest vehicles. Direct observation of lessons and extra-curricular activities on traffic safety education from grade 1 to grade 5 .

Questionnaire survey method:

Design questions;

Prepare questionnaires to survey administrators, teachers, parents, and students at four primary schools in Ho Chi Minh City.

Interview method: Direct interviews with Principals (Vice Principals in charge), some teachers, and parents of students in elementary schools in four selected primary schools

Professional solution:

Consult experts and teachers with practical experience on the proposed measures;

The functional forces directly handle traffic accidents, the forces coordinate with the school to coordinate the implementation of educational measures.

Support method group:

Using mathematical-statistical methods;

Using supporting software: Excel software, SPSS software to process data, make tables.

To survey the current situation of traffic safety education management for elementary school students in Ho Chi Minh City, the author of the thesis builds a poll form for administrators and teachers of primary schools in Ho Chi Minh City. The scoring convention for the questionnaire: Each item has options and is determined by different score levels, specifically:

Table 1 - Standard scoring for each rating level

\begin{tabular}{|l|l|l|l|}
\hline 1 point & 2 point & 3 point & 4 point \\
\hline Uunnecessary & Less necessary & Necessary & Very necessary \\
\hline No affect & Wondering & Affect & Very influential \\
\hline
\end{tabular}

Source: Prepared by the authors 
How to rate:

The processing of the results of the polls is based on the quantitative statistical method of the research results. The topic uses two assessment methods: the quantitative method and the scoring method. Specifically:

The assessment standard with questions has 4 levels of answer questions as follows:

Question 4 answer levels, rated according to the following levels:

Level 4: Good (Very influential; Very necessary): $3.26 \leq \overline{\mathbf{X}} \leq 4.00$.

Level 3: Fair (Affect; Necessary): $2.51 \leq \overline{\mathbf{X}} \leq 3.25$.

Level 2: Moderate (Less necessary; Wondering): $1.76 \leq \leq 2.50$.

Level 1: Weak (Not affect; Not necessary): $1.00 \leq \leq 1.75$.

Use mean $\overline{\mathbf{X}}$ :

The average score in statistics represents the degree of representation according to a certain quantity criterion of a homogeneous population consisting of many units of the same type. The average score reflects the average level of the phenomenon and compares two (or more) populations of the same type of phenomenon, which are not of the same size.

Use the formula to calculate the average score:

$$
\bar{X}=\frac{\sum_{i=n}^{k} X_{i} K_{i}}{n}
$$

$\overline{\mathbf{X}}$ : Medium score.

Xi: Score at level i.

$\mathrm{Ki}$ : Number of participants rated at Xi level.

$\mathrm{n}$ : Number of people participating in the assessment.

\section{Literature Review}

Every country in the world, in any stage of development, has to face challenges and negatives arising in society such as natural disasters, epidemics, poverty, environmental pollution, population explosion. number, traffic accident, etc. In order to solve these negative challenges, each country will choose for itself different solutions to match that actual situation. One of the fundamental and long-term solutions is education.

Education plays an extremely important role in equipping students with knowledge and forming personalities. Educational activities taking place in schools have great meaning and role in shaping ideas, building ideas, ethics, culture, lifestyle, and basic laws for learners. 
The issue of traffic safety is no exception to that fundamental issue. Therefore, traffic safety education activities right from the time you are at school is an extremely necessary, strategic, long-term, and highly effective job.

Kan (2013), in "Studies on School Bus, Case study of UK Experiences, Comparative Education Review (in Chinese), 9(1), on the basis of comparison of traffic safety education activities in the UK and China concluded on comparative educational differences between the two countries; indicate the nature of the difference; the influence of cultural factors on traffic safety education activities for students such as China is more inclined to transmit knowledge, experience in legal education, in the UK it focuses on practical activities and implements many legal exchanges in class, etc.

At the 2nd Global Summit on Road Traffic Safety (December 2015) held in Brazil, $130 \mathrm{UN}$ member states adopted the Brazilian Declaration on road traffic safety in the world. The Brazilian Declaration specifically emphasizes educational activities, raising people's awareness when participating in traffic such as compliance with the laws of the host country, educating the sense of personal protection, etc.

India Today (2019), in the article "School education is the key to developing character, building social and life skills" has pointed out: Education in school is something that builds the foundation of an individual's life, shaping an individual's life. one's life, determines one's character, morals, ideals, principles, life skills, and everything necessary to have a good life and career.

In Vietnam, in addition to the guidelines of the Party, legal documents of the State stipulating and disseminating traffic safety, urgent conferences discuss methods and methods of implementation to limit traffic accidents and raise the awareness of traffic safety. People participating in traffic also mention the following specialized research theses and theses, specifically:

Dinh Loc (1987), Legal consciousness and legal consciousness education in Vietnam, Ph.D. thesis in Law, National Academy of Politics, Hanoi;

Hoang Tram (2003), Measures to improve the quality of educational management outside of class time by principals of some primary schools in the South, Master's Thesis in Educational Management, University of Education, Hanoi Interior;

Kim Dung (2004), Completing the law on education in Vietnam today, Master's Thesis in Law, Ho Chi Minh National Academy of Politics, Hanoi; 
Chien (2008), Research on the behavior of obeying the Road Traffic Law of middle school students when participating in traffic, Ph.D. thesis, Vietnam Academy of Social Sciences, etc.

Researches on traffic safety and traffic safety education for students have confirmed the very important position and role in the education of young generations in Vietnam and many countries around the world. However, up to now, there has not been any research that systematically, comprehensively, and deeply studied the management of education safety education for students in primary schools. Therefore, this study will focus on analyzing the current situation, the need, and the problems posed in the management of traffic safety education for pupils in primary schools.

\section{Results and Discussion}

\section{The Position And Role Of Traffic Safety Education In Primary Schools}

Traffic safety education in high schools is one of the educations that play an important role in the educational process of forming and comprehensively developing the young generation's personality in the current period. Traffic accidents and frustrations about traffic are always problems with heavy pressure on society. Statistics show that more than $90 \%$ of accidents are caused by vehicle drivers violating traffic laws. In which, there are many accidents that leave extremely pitiful consequences when the victims are students sitting on school chairs, due to ignorance, they did not anticipate the incident (DIRECTORATE FOR ROADS, 2020)

Primary school students do not know how to safely participate in traffic: Recent studies have shown that students are the most vulnerable when participating in traffic by electric motorbikes and electric bicycles. According to the data of the Vietnam Association of Motorcycle Manufacturers, in August 2016, 20 children died from traffic accidents for every 100,000 children, a rate three times higher than that of other countries in the region. In which, more than $80 \%$ of accidents occur when children are directly driving vehicles.

Therefore, the high school has the duty to cooperate with family and society to organize education with traffic safety content in order to raise awareness and responsibility for students when participating in traffic. 


\section{Current Status Of Traffic Safety Education Management In Primary Schools}

Organizing the implementation of the traffic safety education plan in primary schools in the process of designing the apparatus, arranging, arranging, using, and developing resources to achieve the common goal. The essence of the organizational function is to perform a reasonable division of labor, in order to maximize the ability of human resources to effectively implement the common goal. In order to assess the actual situation of organizing and implementing traffic safety education in primary schools, the author uses questions, and through processing, the results are shown in Table 2.

Table 2 - The actual situation of organizing and implementing traffic education activities for primary school pupils

\begin{tabular}{|c|c|c|c|c|c|c|c|c|}
\hline \multirow[b]{2}{*}{$\begin{array}{c}\text { Organize the implementation of traffic } \\
\text { safety education }\end{array}$} & \multicolumn{3}{|c|}{ Awareness level } & \multicolumn{5}{|c|}{ Perform } \\
\hline & 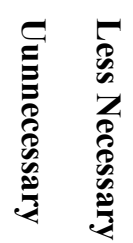 & 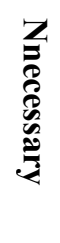 & 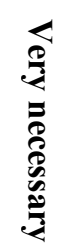 & 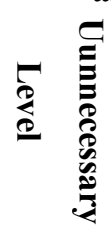 & $\begin{array}{l}5 \\
0 \\
0 \\
z \\
0 \\
0 \\
0 \\
0 \\
0 \\
3 \\
3\end{array}$ & 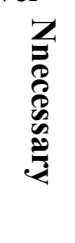 & 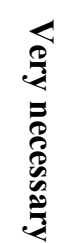 & 帛 \\
\hline
\end{tabular}

Principal Establishes a steering committee to organize traffic safety education in primary schools.

The principal organizes the dissemination of legal documents to all staff, teachers, and students in the school.

Clearly define the authority and responsibility for each stage of management, in which special attention is paid to clearly define the interrelationships between departments in the process of traffic safety education.

The principal assigns the tasks of the sections in the organizational structure of traffic safety education.

The principal has well-built the core team to implement traffic safety education through collective activities

The principal assigns management responsibilities in the school administration.

Assign the core team to implement traffic safety education.

The principal clearly establishes and implements the coordination mechanism for traffic safety education management.

The principal determines a mechanism to coordinate with the local government and Team Leader to implement the activities and create a 4

20

.74

$\begin{array}{lllllll}6 & 1.3 & 2 & \mathbf{0 8} & 0 & 4 & 1\end{array}$

$\begin{array}{lllllllll}8 & 2 & 1.1 & 3 & .35 & 0 & 2 & 8 & .64\end{array}$

$\begin{array}{lllllllll}6 & 0 & 0 & 8 & . \mathbf{6 0} & & 9 & 4 & \mathbf{. 6 3} \\ 5 & 3 & 1 & 5 & \mathbf{. 3 1} & 0 & 8 & 0 & \mathbf{. 3 1}\end{array}$

\begin{tabular}{|c|c|c|c|c|c|c|c|c|c|c|}
\hline 1 & 8 & 8 & & .25 & & 8 & 4 & 0 & & .95 \\
\hline 3 & 0 & 9 & 2 & .12 & & 8 & 4 & 2 & 0 & .17 \\
\hline 3 & 6 & 9 & & .10 & 0 & 8 & 0 & 2 & & .90 \\
\hline
\end{tabular}

close relationship with the locality and

RPGE-Revista on line de Política e Gestão Educacional, Araraquara, v. 25, n. 3, p. 2535-2551, Sep./Dec. 2021. e-ISSN: 1519-9029 DOI: https://doi.org/10.22633/rpge.v25i2.15840 


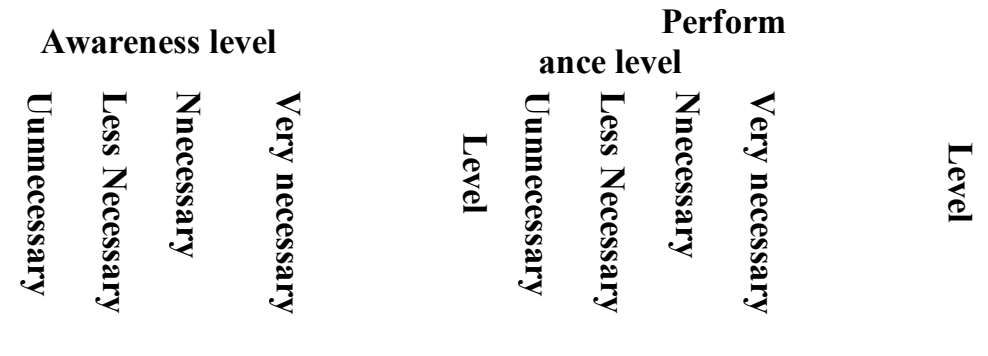

mobilize the potential of the locality in the organization of education. Traffic Safety.

The principal shall coordinate with the local police to propagate the Traffic Law and Decree. Detecting and preventing students in school from 76 $6 \quad .12$ 15 $5 \quad .14$ violating traffic safety.

Source: Prepared by the authors

The actual situation of organizing and implementing traffic safety education in primary schools in schools is assessed at 2 levels: regularity with assessment results with 2.10 to 3.08 in which the level of implementation is only from 1.97 to 2.88 . Specifically, each content is as follows:

The frequency and level of implementation are quite good in the criterion "Principal Establishes a steering committee to organize traffic safety education in primary schools" (the frequency with $\overline{\mathrm{X}}=2.74$ ranked $1 / 10$. The level of performance with $\overline{\mathrm{X}}=2.88$ ranked $1 / 10$ ). Then there is the criterion, "The principal organizes the dissemination of legal documents to all staff, teachers, and students in the school" (the frequency with $\overline{\mathrm{x}}=3.08$ ranked $1 / 10$. The level of performance with $\overline{\mathrm{X}}=2.85$ ranked 2/10). Through practice, schools have organized to disseminate legal documents to all staff, teachers, and students in the school. In the past time, the school has organized implementation, training, and integrated into special activities, leaders of the school have organized to guide teachers to develop professional plans, organizational Traffic safety education organization through classroom teaching hours and out-of-classroom teaching hours. Propaganda through seminars, forums, seminars, organizing festivals, contests to learn about Traffic Law, theatricalization of activities; through flagraising sessions, class activities, activities in charge of Teams, Associations and Teams; through the internal radio system, etc.

Propaganda, integrated education, integrated through the main teaching hours, through extracurricular activities; pay special attention to expanding propaganda to parents of students.

The next advantage is "Clearly defining the authority and responsibility for each management stage, in which special attention is paid to clearly defining the interrelationships 
between departments in the process of traffic safety education". Through research, the Rector has coordinated with relevant local departments and agencies to continue building a model of Traffic Safety School Gate and strengthen propaganda and education to raise awareness and self-discipline to obey the law. when participating in traffic; traffic culture and safe traffic skills for pupils. In it, the contents are: "The principal coordinates with the local police to propagate the Traffic Law and Decree. Detect and prevent students in school from violating traffic safety; The principal clearly establishes and implements a mechanism for coordination in traffic safety education management", etc. still has many limitations.

With the organization of traffic safety education in primary schools, certain advantages have been achieved, although there are incentives and encouragements for teachers to promote their abilities and intelligence for that activity. However, all the elements in the guiding process have not been fully exploited. Specifically, directing to promote the conditions of existing facilities and equipment, especially not synchronized, have not mobilized many resources for this activity, still passive in handling situations that occur. in the process of implementation, bring into full play the role of the steering committee, coordination, and cohesion among the participating forces. Thereby partly shows that managers have not done well in their role of advising, advising, and operating activities, and have not coordinated closely with other educational forces inside and outside the school. That requires management measures to overcome this problem, thereby ensuring the quality of traffic safety education in primary schools.

\section{The actual situation of factors affecting the management of traffic safety education activities in primary}

The actual situation of traffic safety education management for primary school pupil in Ho Chi Minh City today has many dominant reasons. The topic focuses on surveying the causes to find out the level of influence, the results are shown in the following statistical table (Table 3). 
Table 3 - The actual situation of factors affecting the management of traffic safety education activities in primary schools

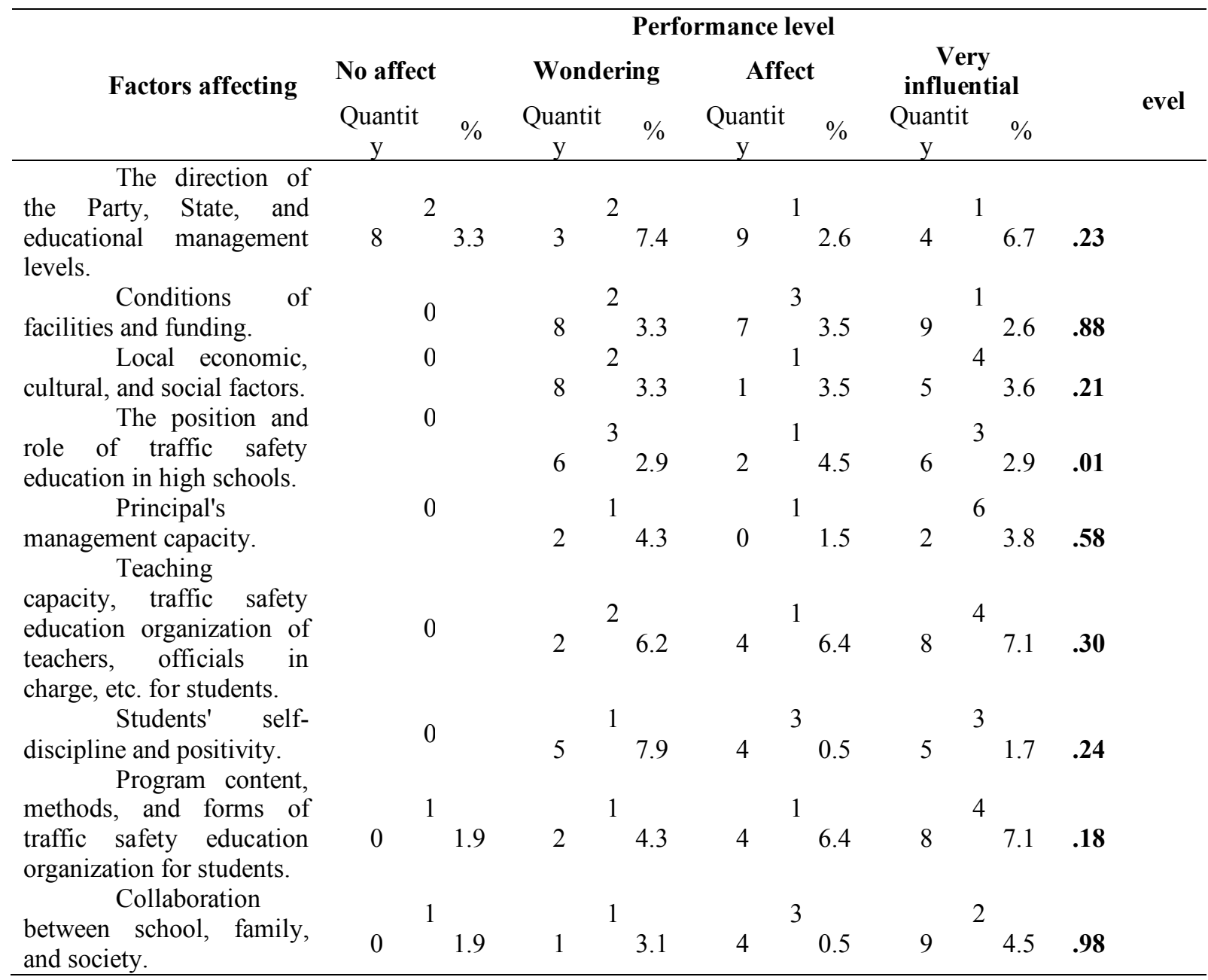

Source: Prepared by the authors

The survey results show that the above factors all affect and greatly affect the management of traffic safety education for elementary school pupils in Ho Chi Minh City as follows:

The biggest influence on the situation is the "management capacity of the principal" with an average value of 3.58 , followed by "The capacity to teach and organize traffic safety education of teachers, officials in charge for students" has $\bar{x}=3.30$. Ranked 3rd with the average score $\overline{\mathrm{x}}=3.24$ is the content "Student's self-discipline and positivity". Ranked 4th with the average score $\overline{\mathrm{x}}=3.21$ is the content "Local economic, cultural and social factors".

Survey results by direct interview, the majority of teachers also believe that the "human" factor, including the "mind" and the "reach" of the manager and the direct implementer, is the factor. make an important contribution to the principal in directing the implementation of traffic safety education in primary schools effectively; content, methods, facilities conditions, and supporting means have a direct influence. It proves that the above 
reasons all affect the situation of traffic safety education management for primary school students. Especially noteworthy is the capacity and quality of the management subject, teacher, content, organizational form, etc. It is necessary to have solutions that affect the causes in order to achieve the desired results.

Thus, in order to carry out traffic safety education for primary school students, it requires appropriate conditions in terms of means, facilities, and educational organization, and conditions on organization and management. In addition, it is necessary to have separate policies to reward and motivate good teachers to achieve high achievements or special remuneration policies for teachers to actively participate in traffic safety education for primary school pupils and have experience initiatives. The above research results will be the basis for building implementation measures.

\section{Conclusion}

Through the actual situation of traffic safety management in primary schools in Ho Chi Minh City, we can give some results:

Management of traffic safety education activities in primary schools in Ho Chi Minh City has been carried out in accordance with the actual situation of the locality and achieved certain effects. However, the level of awareness is still not really deep, the content is poor, the methods and forms of education are even more monotonous, and the physical and financial conditions have not brought into full play the full effect of the curriculum. educational work. There are many influencing factors, the most prominent being the awareness and capacity of the ministries and branches, the motivation, the qualifications of the Rector, the program content as well as the unrealistic form of education.

The situations analyzed and presented above are both contradictory and become difficulties and represent inadequacies in the organization of traffic safety education activities in primary schools in Ho Chi Minh City.

Thus, it is necessary to have management methods to remove difficulties and overcome inadequacies to ensure effective traffic safety activities in primary schools in Ho Chi Minh City in order to contribute to improving the efficiency of traffic safety. The management capacity of the Principal in general and primary education, in particular, meets the requirements of educational innovation in the context of current socio-economic development. 
ACKNOWLEDGMENTS: The authors declare no conflict of interest in the publication of the manuscript. The first author and also the sole author contributed to data analysis, translation, study design, and manuscript preparation.

\section{REFERENCES}

AULT, H. J.; GLENDON, M. A. The importance of comparative law in legal education: united states goals and methods of legal comparisons. Journal of Legal Education, v. 27, p. 599-608, 2005.

COLUCCI, B.; MELÉNDEZ, I.; SEÑERIZ, S. "Innovative Programs and Action Plan to Raise Road User Awareness in the Commonwealth of Puerto Rico Supporting the Decade of Action for Road Safety". Second Traffic Forum, v. 4, n. 6, p. 206-213, 2013.

CHIEN, N. N. Research on the behavior of obeying the Road Traffic Law of junior high school students when participating in traffic. 2008. Thesis (Ph.D.) - Vietnam Academy of Social Sciences, Hanoi, 2008.

DAO, N. V; VAN, V. H. Social Network And Its Impact On Psychology And Learning Attitude Of Students: The Study Case Freshman Students At Universities Of Ho Chi Minh City. Journal of Natural Remedies, v. 21, n. 8/1, p. 163-175, 2020.

DIRECTORATE FOR ROADS. Report on road traffic violations for 2 years (2018 and 2019), solutions in 2020. 2020.

DUC HIEP, H.; PHONG, N. X.; HONG VAN, V. Change the methods of higher education: necessity, barriers difficulties and solution. Journal of Natural Remedies, v. 21, n. 8/1, p. 150-162, 2020.

GOVERNMENT. Resolution No. 14/2005/NQ - CP dated November 2, 2005. On a fundamental and comprehensive renovation of higher education. Hanoi, Vietnam, 2005.

HIEN, N. T. "Improving the awareness of road traffic law enforcement for students in the current period". Journal of Education, n. esp., p. 57-64, 2015.

HO CHI MINH COMMUNIST YOUTH UNION CENTRAL COMMITTEE. Overview of youth situation and youth work 2015-2018. Hanoi: Youth, 2019.

INDIA TODAY. School education is the key to developing character, building social and life skills. 2019. Available: https://www.indiatoday.in/educationtoday/featurephilia/story/school-education-is-the-key-to-developing-character-buildingsocial-and-life-skills-1631128-2019-12-24. Access: 10 Mar. 2021.

KAN, W. Studies on School Bus, Case study of UK Experiences, Comparative Education Review (in Chinese). Journal of Law Education, v. 9, n. 1, p. 48-56, 2013.

LE THUY HANG, VU HONG VAN. Building strong teaching and learning strategies through teaching innovations and learners' creativity: a study of vietnam universities. 
International Journal of Education and Practice, v. 8, n. 3, p. 498-510, 2020. DOI: 10.18488/journal.61.2020.83.498.510

LUONG, P. V.; VAN, V. H. Education responsibility protection environmental for students: duties, requirements and necessity. Journal of Contemporary Issues in Business and Government, v. 27, n. 1, p. 155-166, 2021.

MINISTRY OF JUSTICE. Circular No. 01/2003/TT-BTP dated March 14, 2003. Guiding the implementation of Resolution No. 13/2003/QD-TTG dated January 17, 2003, approved by the Prime Minister law dissemination and education program from 2003 to 2007. Hanoi, 2003.

NATIONAL TRAFFIC SAFETY COMMITTEE. Report summarizing 5 years of implementation of the emulation movement to ensure traffic safety in the period 20162020 and results in the year of traffic safety 2020, implementing key tasks in the period 2021-2025. 2020.

THE CENTRAL COMMITTEE OF THE COMMUNIST PARTY OF VIETNAM. Directive No. 18-CT/TW of the Secretariat of the 11 th term on strengthening the leadership of the Party in ensuring traffic safety on roads, railways, and roads inland waterways and overcome traffic jams. 2019.

THE CENTRAL COMMITTEE OF THE COMMUNIST PARTY OF VIETNAM. Document No. 242-TB/TW dated April 15, 2009, announcing the conclusion of the Politburo on continuing to implement the Central Resolution 2 (term VIII). Directions for the development of education and training to 2020. 2009.

THE CENTRAL COMMITTEE OF THE COMMUNIST PARTY OF VIETNAM. Resolution No. 29-NQ/TW dated November 4, 2013, of the Party Central Committee on fundamental and comprehensive reform of education and training, meeting meet the requirements of industrialization and modernization in the context of a socialistoriented market economy and international integration. 2013.

TRUNG, N. S.; VAN, V. H. Educating Traditional Cultural Values in Vietnam Universities. South Asian Research Journal of Humanities and Social Sciences, v. 2, n. 3), p. 210-214, 2020 .

TRUNG, N. S.; VAN, V. H. Vietnamese Cultural Identity in the Process of International Integration. Journal of Advances in Education and Philosophy, v. 4, n. 6, p. 220- 225, 2020 .

VAN, V. H. Identify Methods Of Teaching And Learning To Create Interest, Self-Study, And Creativity Of Students. Humanities \& Social Sciences Reviews, v. 8, n. 3, p. 646-656. DOI: https://doi.org/10.18510/hssr.2020.8369

VAN, V. H. Social Responsibility Of Students: The Role And Importance Of Education. Journal of Natural Remedies, v. 21, n. 8/1, p. 241-254. 


\section{How to reference this article}

VU HONG, V. Managing traffic safety education activities in primary schools: status, necessity, and influencing factors. Revista online de Política e Gestão Educacional, Araraquara, v. 25, n. 3, p. 2535-2551, Sep./Dec. 2021. e-ISSN: 1519-9029. DOI: https://doi.org/10.22633/rpge.v25i2.15840

Submitted: $15 / 09 / 2021$

Required revisions: $17 / 10 / 2021$

Approved: $18 / 11 / 2021$

Published: 08/12/2021 